\title{
Digestible Lysine Requirements the Performance, Carcass Traits and Breast Meat Quality of Slow- Growing Broilers
}

\section{mAuthor(s)}

\section{Brasil RJM' \\ Lima CAR" \\ Machado NJB"I \\ Curvello FA' \\ Quaresma DVIII \\ Vieites FM ${ }^{\mathrm{V}}$ \\ Sousa FDR"I}

Graduate student in Biodiversity and Biotechnology, Universidade do Estado do Amazonas, Rede Bionorte, Manaus, AM, Brazil.

" Ph. D. in Animal Science, Universidade Federal Rural do Rio de Janeiro (UFRRJ), Departamento de Nutrição Animal e Pastagens, Seropédica, RJ, Brazil.

III Graduate student in Animal Science, Universidade Federal Rural do Rio de Janeiro (UFRRJ), Departamento de Produção Animal, Seropédica, RJ, Brazil.

Iv Ph. D. in Animal Science, Universidade Federal Rural do Rio de Janeiro (UFRRJ), Departamento de Produção Animal, Seropédica, RJ, Brazil

$\checkmark$ Ph. D. in Animal Science, Universidade Federal de Juiz de Fora / UFJF, Juiz de Fora, MG, Brazil.

\section{-Mail Address}

Corresponding author e-mail address Ronner Joaquim Mendonça Brasil

Universidade do Estado do Amazonas, Rede Bionorte - Av. Carvalho Leal, 1777,

Cachoeirinha, CEP: 69065-130 - Manaus - AM - Brasil.

Phone: (92) 99149-5390

Email: ronnerjoaquim_rj@hotmail.com

\section{- Keywords}

Amino acid, meat quality, lysine requirements, slow-growing broilers.

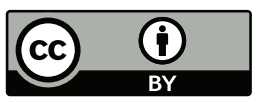

Submitted: 03/November/2017 Approved: 08/March/2018

\section{ABSTRACT}

Three experiments were conducted to estimate the digestible lysine requirements of slow-growing broilers on their performance, carcass traits, and breast meat quality. Different broilers were evaluated in each experiment. In Experiment 1, broilers were evaluated from 2949 days of age (grower phase I), in Experiment 2, from 50 to 69 days old (grower phase II), and in Experiment 3, from 70-84 days old (finisher phase). A completely randomized design with five treatments of four replicates each was applied in all experiments. The following dietary digestible lysine values were investigated: 0.871, 1.011, 1.151, 1.291 and $1.431 \%$ in Experiment 1; 0.803, 0.943, 1.083, 1.223 and $1.363 \%$ in Experiment 2 ; and $0.766,0.906,1.046,1.186$ and $1.326 \%$ in Experiment 3. In all three experiments, digestible lysine values quadratically affected feed intake, weight gain, and feed conversion ratio. Lysine intake linearly increased with increasing digestive lysine values, whereas lysine utilization efficiency linearly decreased. Lysine requirements for maximum feed intake $(1.298,1.109,1.150 \%)$, weight gain $(1.183,1.199,1.162 \%)$, and feed conversion ratio (1.203, 1.162, 1.126\%) were estimated in Experiments 1, 2 and 3. Digestible lysine requirement for carcass yield were estimated as 1.162, 1.068 and $1.107 \%$ in experiments 1, 2 and 3, respectively. Lysine influenced the physical-chemical parameters broiler breast meat. Digestible lysine levels of $1.203,1.162$ and $1.126 \%$ are recommended in the diets of Redbro Plume broilers during the phases $29-49,50-69$ and $70-84$ days of age to optimize feed conversion ratio.

\section{INTRODUCTION}

Lysine is an essential amino acid and it is often the second limiting amino acid in diets based on corn and soybean meal. Lysine has considerable quantitative importance in the diet and is directly involved in the body development of poultry. It is an essential amino acid with a significant physiological function in muscle protein synthesis (Costa et al., 2001; Lana et al., 2005). In addition, lysine is a constituent of basic structures, such as collagen because it is precursor of the hydroxylysine (Sandel \& Daneil, 1988), as well as of elastin, histones, carnitine (Champe et al., 2009) and digestive enzymes.

Lysine is the main amino acid taken into account in feed formulations based on the ideal protein concept, where the requirements of other amino acids are estimated in proportion to lysine (Pedroso et al., 2003). Therefore, determining the proper lysine requirement is essential for the formulation efficient feeds, with no limitations or excess of amino acids. Lysine -limiting diets have direct negative effects on muscle development, thus affecting the performance, carcass characteristics, and body composition of broilers (Oliveira et al., 2013). 
Brasil RJM, Lima CAR, Machado NJB, Curvello FA, Quaresma DV, Vieites FM, Sousa FDR



Digestible Lysine Requirements the Performance, Carcass Traits and Breast Meat Quality of SlowGrowing Broilers
Several studies have been carried out to evaluate the responses of broilers to different lysine concentrations in the diet and to determine broiler lysine requirements for efficiency, performance, and carcass composition (Alam et al., 2012). However, the formulation of diets for slow-growing broilers are typically based on the nutritional requirements established for geneticallyimproved broilers with high growth potential, as there is little information regarding the growth requirements for slow-growing broilers, which may limit the efficiency of feed utilization and compromise the final profitability.

The CobbSasso150 (Cobb-Vantress, 2008) slowgrowing broiler strain manual recommends digestible lysine values of $1.22 ; 1.08$ and $1.00 \%$ for the starter, grower and finisher phases, respectively, and Nascimento et al. (2009) recommended 1.041, 1.006 and $0.760 \%$ of digestible lysine in the starter, grower and finisher diets of ISA Label chickens.

One of the main parameters used to determine broiler nutritional requirements is the breast, the most expensive carcass part and considered a sensitive indicator of dietary nutrient supply. According to Sklan \& Noy (2004), about $7.5 \%$ of all carcass protein is composed of lysine, and therefore further studies on the evaluation of digestible lysine values in feeds, particularly on its requirement for meat quality, are needed, considering the importance of lysine for the synthesis of muscle protein.

The RedBro Pluméis a slow-growth broiler strain that presents feathered neck, yellowish legs, intense red feathers, tail with black feather, and welldeveloped breast (Miranda et al., 2005). It reaches an average final body weight of $2,200 \mathrm{~kg}$ between 70 and 80 days of age with a feed intake of about 5,700$6,300 \mathrm{~kg}$. It is commonly reared in semi-intensive or extensive systems, and is highly valued in the chicken meat market.

The objectives of the present study were to estimate the digestible lysine requirements of broilers with low genetic growth potential between 29 and 49 days, 50 to 69 days, and 70 to 84 days, using performance evaluations, carcass characteristics, and breast meat quality.

\section{MATERIAL AND METHODS}

\section{Birds and housing}

Three experiments were conducted at the Poultry Production Integrated Center of the Universidade Federal Rural do Rio de Janeiro (UFRRJ), located at latitude $22^{\circ} 45^{\prime} \mathrm{S}$ and longitude $43^{\circ} 41^{\prime} \mathrm{W}$. The experiments were approved by the Ethics Committee on Animal Use (ECAU) of the Institute of Animal Science of UFRRJ, process number 23083.011133 / 2014-48.

A total of 1,200 one-d-old RedbroPlumé male broiler chicks (average weight $=40.4 \mathrm{~g}$ ) were housed in a conventional broiler house. Birds were vaccinated in the hatchery against Marek's disease and fowlpox. Water and feed were supplied ad libitum while broilers remained in the house before being transferred to the experimental facilities.

Three experiments were carried out. Experiment 1 corresponds to grower phase I (29 to 49 days), experiment 2 to grower phase II (50 to 69 days), and experiment 3 to the finisher phase (70 to 84 days). In each experiment, different birds were used.

The experimental shed was divided in 20 pens $(4 \mathrm{~m}$ $\times 5 \mathrm{~m}$ each), equipped with a bell drinker and two tube feeders. The floor was covered with wood shavings ( \pm $8 \mathrm{~cm}$ thick). Feed and water were provided ad libitum throughout the experiment. The lighting regime of 16 hours of light and 8 hours of darkness was applied in accordance with the recommendations of the Normative Instruction N. 46 of the Brazilian Ministry of Agriculture (Brasil, 2011).

Prior to the start of each experiment, the feeds supplied were formulated according to Rostagno et al. (2011).

\section{Diets and experimental design}

The experiments were conducted according to a completely randomized design, with five treatments with four replicates each, totaling 20 experimental units. Each replicate consisted of 22 broilers in experiment 1 ; 20 in experiment 2; and 18 in experiment 3, totaling 440 birds in experiment 1, 400 animals in experiment 2 and 360 in experiment 3 . Birds were selected according to body weight uniformity, and all birds remained in the shed until the end of each experiment.

For the chemical and physical-chemical analysis of breast meat (experiments 2 and 3), the breast of two broilers per replicate were collected after slaughter, totaling eight breasts per treatment.

The basal diets (Table 1) were formulated to contain all nutrients as recommended by Rostagno et al. (2011), except for lysine, calcium and phosphorus. The criterion to determine the nutritional requirements was average body weight (BW), instead of age as described in the tables. The calcium and available phosphorus requirements used for feed formulation were based 
Brasil RJM, Lima CAR, Machado NJB, Curvello FA, Quaresma DV, Vieites FM, Sousa FDR

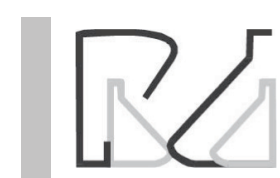

Digestible Lysine Requirements the Performance, Carcass Traits and Breast Meat Quality of SlowGrowing Broilers on Pinheiro et al. (2011a) and Pinheiro et al. (2011b). Corn gluten, an ingredient that is limiting in lysine, was included in all experimental diets with the aim of obtaining a basal lysine value without decreasing the crude protein value of the diet.

Table 1 - Ingredients and calculated nutritional composition of the basal diets in each experiment.

\begin{tabular}{|c|c|c|c|}
\hline \multirow[t]{2}{*}{ Ingredient $\left(\mathrm{g} \mathrm{kg}^{-1}\right)$} & \multicolumn{3}{|c|}{ Experiments } \\
\hline & 1 & 2 & 3 \\
\hline Corn $(7.88 \% C P)^{1}$ & 63.253 & 66.166 & 66.975 \\
\hline Soybean meal $\left(46.90 \%\right.$ CP) ${ }^{1}$ & 28.493 & 25.893 & 24.369 \\
\hline Soybean oil & 2.257 & 2.689 & 3.034 \\
\hline Corn gluten $(60.09 \% \mathrm{CP})^{1}$ & 2.037 & 1.299 & 1.369 \\
\hline Dicalcium phosphate & 1.195 & 1.223 & 1.378 \\
\hline Limestone & 0.843 & 0.842 & 1.014 \\
\hline Corn starch & 0.900 & 0.900 & 0.900 \\
\hline DL-Methionine (98.5\%) & 0.247 & 0.234 & 0.219 \\
\hline L-Threonine (98.5\%) & 0.057 & 0.059 & 0.054 \\
\hline Mineral mix² & 0.100 & 0.100 & 0.100 \\
\hline Vitamin $\mathrm{mix}^{3}$ & 0.100 & 0.100 & 0.100 \\
\hline Salt & 0.457 & 0.444 & 0.438 \\
\hline Choline chloride (60\%) & 0.050 & 0.040 & 0.040 \\
\hline Antioxidant $(\mathrm{BHT})^{4}$ & 0.010 & 0.010 & 0.010 \\
\hline Total & 100.00 & 100.00 & 100.00 \\
\hline \multicolumn{4}{|l|}{ Nutritional composition $(\%)^{5}$} \\
\hline Crude protein & 19.761 & 18.322 & 17.700 \\
\hline Metabolizable energy (Kcal/kg) & 3,100 & 3,150 & 3,175 \\
\hline Linoleic acid & 2.680 & 2.928 & 3.112 \\
\hline Available phosphorus ${ }^{6}$ & 0.350 & 0.335 & 0.320 \\
\hline Calcium $^{7}$ & 0.780 & 0.735 & 0.690 \\
\hline Sodium & 0.200 & 0.195 & 0.192 \\
\hline Digestible methionine+cystine & 0.796 & 0.745 & 0.717 \\
\hline Digestible methionine & 0.523 & 0.490 & 0.469 \\
\hline Total lysine $^{8}$ & 0.987 & 0.912 & 0.874 \\
\hline Digestible lysine & 0.871 & 0.803 & 0.776 \\
\hline Digestible threonine & 0.709 & 0.663 & 0.638 \\
\hline Digestible valine & 0.825 & 0.763 & 0.738 \\
\hline Digestible isoleucine & 0.748 & 0.687 & 0.661 \\
\hline Digestible arginine & 1.157 & 1.070 & 1.026 \\
\hline
\end{tabular}

'Values determined at the Animal Nutrition Laboratory DNAP / IZ.

${ }^{2}$ Guaranteed levels/kg product: $50 \mathrm{~g}$ iron; $8,500 \mathrm{mg}$ copper; $1,000 \mathrm{mg}$ cobalt; $1.000 \mathrm{mg}$ iodine; $70 \mathrm{~g}$ manganese, $60 \mathrm{~g}$ zinc.

${ }^{3}$ Guaranteed levels/kg product: 12,000,000 IU Vitamin A (i);2,250,000 IU Vitamin D3;25,000 IU Vitamin E (i); 3,000 mg Vitamin K3; 2.400mg Vitamin B1 (thiamine); $12 \mathrm{~g}$ Vitamin B2 (riboflavin);2,000 mg vitamin B6 (pyridoxine);24,000 mg vitamin B12 (i); $42 \mathrm{~g}$ niacin (me), $15 \mathrm{~g}$ calcium pantothenate; $1,800 \mathrm{mg}$ folic acid; $50 \mathrm{mg}$ BHT; $180 \mathrm{mg}$ biotin; $180 \mathrm{mg}$ selenium.

${ }^{4}$ BHT (butylated hydroxytoluene).

${ }^{5}$ Brazilian Tables for Poultry and Swine.

6,7Pinheiro et al. (20011a, 2011b).

${ }^{8}$ Analyzed amino acid.

In all experiments, the treatments consisted of five diets with increasing digestible lysine values, obtained by the addition of L-Lysine $\mathrm{HCl}$ (78\% purity) to the basal diet in replacement of cornstarch. The treatments were as follows: $0.871,1.011,1.151,1.291$ and $1.431 \%$ digestible lysine in experiment $1 ; 0.803,0.943,1.083$, 1.223 and $1.363 \%$ digestible lysine in experiment 2 ; $0.766,0.906,1.046,1.186$ and $1.326 \%$ digestible lysine in experiment 3.

\section{Measurements}

The variables evaluated in each experiment were feed intake, weight gain, feed conversion ratio, lysine intake, and lysine utilization efficiency (related to digestible lysine intake). Carcass and parts yields (breast, wing, thigh + drumstick and back) and relative weights of edible viscera (gizzard, liver and heart) and of abdominal fat. Carcass yield and the relative weights of edible viscera and abdominal fat were determined as their weight relative to slaughter weight. Parts (breast, wing, thigh + drumstick and back) yield was determined as part weight relative to cold carcass weight. Breast meat quality parameters (chemical and physical-chemical composition) were also measured in experiments 2 and 3 .

At the end of each experiment, four broilers per replicate were selected based on the representative average weight of the replicates, totaling 16 chickens per treatment. Birds were subjected to eight-hour fasting, after which they were weighed, sacrificed by cervical dislocation, bled, plucked, and their viscera, head, neck and feet were removed. Carcasses were then chilled, dripped for 5 min to reduce the excess of water absorbed in the previous step, and submitted to standard commercial cut-up. The breasts were stored at $\pm 4^{\circ} \mathrm{C}$ until analyses.

\section{Chemical and physical-chemical analyses}

The analyses of the chemical composition of the breast meat were carried out in the Laboratory of Animal Nutrition of the Institute of Animal Science (IZ / UFRRJ); and the physical-chemical analyses in the Laboratory of Food Technology (IT / UFRRJ).

The frozen breasts were thawed in a refrigerator at approximately $10{ }^{\circ} \mathrm{C}$ for a period of 24 hours, and all visible fat and skin were removed before chemical and physical analyses.

The muscular portion of the breast (pectoralis major) of two broilers per experimental unit was removed to determine its chemical composition, including moisture, crude protein, ether extract, and ash contents, according to Silva \& Queiroz (2006).

The following physical-chemical parameters of the breast meat were determined: thawing loss (DL), cooking weight loss $(\mathrm{CL})$, shear strength (SS), $\mathrm{pH}$ and color. 
Brasil RJM, Lima CAR, Machado NJB, Curvello FA, Quaresma DV, Vieites FM, Sousa FDR

\section{Digestible Lysine Requirements the Performance, Carcass Traits and Breast Meat Quality of Slow- Growing Broilers}

\section{Statistical analysis}

The obtained data were submitted to analysis of variance using the statistical program SISVAR (version 5.6) (Ferreira, 2011). Responses were considered significant when at $p<0.05$. The responses to dietary lysine levels were studied by analysis of regression. Estimates of digestible lysine requirements were determined, when possible, using a quadratic model.

\section{RESULTS AND DISCUSION}

\section{Experiment 1 - Performance and carcass traits during grower phase I (29-49 days of age)}

There was a quadratic influence of dietary digestible lysine levels on feed intake, weight gain and feed conversion ratio, and linear influence on lysine intake and utilization efficiency (Table $2)$. The greatest weight gain (1149 g) and best feed conversion ratio (2.24) were obtained with 1.183 and $1.203 \%$ dietary digestible lysine levels, respectively. The results also that the treatment the lowest digestible lysine level $(0.871 \%)$ limited the growth performance of the evaluated birds, as shown by the worst weight gain and feed conversion ratio responses.

The broilers fed the diets with lower digestible lysine values $(0.871 \%)$ presented higher feed intake $(2930 \mathrm{~g})$, probably in an attempt to compensate for amino acid limitation. On the other hand, the higher feed intake obtained as digestible lysine levels increased may be
Breast meat color was determined using a spectrophotometer and the CIELab system. The parameters $L^{*}$ (lightness), $a^{*}$ (redness) and $b^{*}$ (yellowness) were recorded at four different points of the surface of the pectoralis major muscle.

Table 2 - Feed intake, weight gain, feed conversion ratio, lysine intake and lysine utilization efficiency of slow-growing broilers in experiment 1 (29 to 49 days old).

\begin{tabular}{|c|c|c|c|c|c|c|c|}
\hline \multirow[b]{2}{*}{ Variables } & \multicolumn{5}{|c|}{ Digestible lysine (\%) } & \multirow[b]{2}{*}{ Regression* } & \multirow[b]{2}{*}{$\mathrm{CV}^{2}(\%)$} \\
\hline & 0.871 & 1.011 & 1.151 & 1.291 & 1.431 & & \\
\hline Feed intake, $g$ & 2930 & 2830 & 2715 & 2753 & 2733 & Q & 1.63 \\
\hline Weight gain, g & 956 & 1055 & 1108 & 1205 & 979 & Q & 2.60 \\
\hline Feed conversion ratio & 2.87 & 2.52 & 2.31 & 2.16 & 2.61 & Q & 3.63 \\
\hline Lysine intake, g & 25.52 & 28.61 & 31.25 & 35.54 & 39.11 & L & 1.60 \\
\hline LUE$^{1}(\%)$ & 37.48 & 36.89 & 35.47 & 33.91 & 25.04 & $\mathrm{~L}$ & 1.98 \\
\hline
\end{tabular}

${ }^{1} \mathrm{LUE}$, lysine utilization efficiency. ${ }^{2} \mathrm{CV}(\%)$, coefficient of variation; ${ }^{\star} \mathrm{L}$, Linear effect; ${ }^{*} \mathrm{Q}$, quadratic effect $(p<0.05)$. The equations are shown in Table 10.

due to the gradual improvement in the ratio between lysine and other amino acids in the diet, since dietary amino acid balance has a direct effect on voluntary feed intake (Gonzales, 2002).

Nascimento et al. (2009) studied the digestible lysine requirements of Isa Label chickens reared in semi-intensive conditions and estimated a 1.056\% digestible lysine to achieve optimal weight gain. However, Rosa et al. (2014) estimated that 0.908\% digestible lysine should be supplemented into the diet of male broiler chickens at 28-56 days old.

Dietary lysine values had a quadratic effect on carcass, breast and wing yields and a linear effect on leg (thigh + drumstick) yield (Table 3). The highest carcass $(73.62 \%)$ and wing $(27.72 \%)$ yields obtained at estimated digestible lysine values of 1.162 and $1.147 \%$, respectively. The estimated value for breast yield is not recommended because the effect was negative. 
Brasil RJM, Lima CAR, Machado NJB, Curvello FA, Quaresma DV, Vieites FM, Sousa FDR

\section{Digestible Lysine Requirements the Performance, Carcass Traits and Breast Meat Quality of Slow- Growing Broilers}

Table 3 - Relative weights and yields of carcass cuts and edible offal of slow-growing broilers slaughtered at 50 days of age in experiment 1.

\begin{tabular}{|c|c|c|c|c|c|c|c|}
\hline \multirow[b]{2}{*}{ Variables } & \multicolumn{5}{|c|}{ Digestible lysine (\%) } & \multirow[b]{2}{*}{ Regression* } & \multirow[b]{2}{*}{$\mathrm{CV}^{1}(\%)$} \\
\hline & 0.871 & 1.011 & 1.151 & 1.291 & 1.431 & & \\
\hline \multicolumn{8}{|l|}{ Yield (\%) } \\
\hline Carcass & 67.21 & 71.19 & 72.68 & 74.08 & 66.98 & Q & 3.26 \\
\hline Breast & 29.14 & 28.35 & 28.48 & 26.79 & 29.26 & Q & 6.49 \\
\hline Leg & 32.15 & 32.35 & 32.59 & 33.82 & 33.14 & L & 3.40 \\
\hline Wing & 12.98 & 13.12 & 13.64 & 13.10 & 12.96 & Q & 8.58 \\
\hline Back & 29.95 & 27.18 & 28.08 & 26.65 & 29.85 & NS & 10.29 \\
\hline \multicolumn{8}{|c|}{ Relative weight (\%) } \\
\hline Heart & 0.44 & 0.43 & 0.46 & 0.45 & 0.46 & NS & 11.06 \\
\hline Liver & 1.72 & 1.66 & 1.85 & 1.60 & 1.79 & NS & 10.10 \\
\hline Gizzard & 1.95 & 1.84 & 1.84 & 1.77 & 1.94 & NS & 15.96 \\
\hline
\end{tabular}

${ }^{1} \mathrm{CV}$, Coefficient of variation;

${ }^{*} N S$, Not significant; *L, Linear effect; ${ }^{*} Q$, quadratic effect $(p<0.05)$. The equations are shown in Table 10.

The quadratic effect obtained for carcass, breast, and wing yields suggests that digestible lysine levels higher than the estimated requirements possibly reduced lysine utilization efficiency.

The observed increases in carcass and parts yields may be explained by the fact that the main function of lysine is protein deposition in the carcass, and it is one of the main amino acids in muscle proteins. According Sklan \& Noy (2004) about $7.5 \%$ of all carcass protein is composed of lysine.

Rosa et al. (2014) evaluated diets with increasing digestible lysine values fed to male broilers and did not find any effects on carcass and breast yields, obtaining an average carcass yield of $65.44 \%$, which is lower than that found in this study $(73.62 \%)$.

\section{Experiment 2 - Performance, carcass traits, and breast meat quality results obtained in grower phase II (50 to 69 days old)}

\section{Performance and carcass traits}

Dietary lysine values had a quadratic effect on feed intake, weight gain and feed conversion ratio and a linear effect on the lysine intake and utilization efficiency (Table 4). The requirement for maximum weight gain (907 g) was estimated at $1.199 \%$ digestible lysine, and for best feed conversion ratio (3.21) was estimated at $1.162 \%$ digestible lysine. Considering these requirements, when compared with the treatment with the lowest lysine value, weight gain improved in $8.71 \%$ and feed conversion ratio in $5.65 \%$. The lowest feed intake (3492g) during this period was obtained at an estimated digestible lysine level of $1.109 \%$.

The improvement in feed conversion ratio as digestible lysine values increased up to the requirement level is probably due to the positive association between the efficiency of amino acid utilization and the increase in muscle mass or nitrogen retention, since the estimated requirement for weight gain and feed conversion ratio were very close and similar to the results obtained by Almeida (2010).

The manual of the slow-growing broiler strain CobbSasso150 (Cobb-Vantress, 2008) recommends $1.08 \%$ digestible lysine during the growth phase, which is lower than those determined in the present study.

Lysine values influenced in a quadratic manner carcass, breast, leg and wing yields, and the relative weight of abdominal fat (Table 5).

Table 4 - Feed intake, weight gain, feed conversion ratio, and lysine intake and utilization efficiency of slow-growing broilers in experiment 2 (50 to 69 days old).

\begin{tabular}{|c|c|c|c|c|c|c|c|}
\hline \multirow[b]{2}{*}{ Variables } & \multicolumn{5}{|c|}{ Digestible lysine (\%) } & \multirow[b]{2}{*}{ Regression* } & \multirow[b]{2}{*}{$\mathrm{CV}^{2}(\%)$} \\
\hline & 0.803 & 0.943 & 1.083 & 1.223 & 1.363 & & \\
\hline Feed intake, $g$ & 3800 & 3521 & 3523 & 3544 & 3641 & Q & 4.17 \\
\hline Weight gain, g & 828 & 849 & 890 & 940 & 877 & Q & 3.82 \\
\hline Feed conversion ratio & 3.64 & 3.49 & 3.21 & 3.14 & 3.40 & Q & 5.70 \\
\hline Lysine intake, g & 30.51 & 33.20 & 38.15 & 43.35 & 52.10 & L & 4.67 \\
\hline $\operatorname{LUE}^{1}(\%)$ & 36.31 & 39.27 & 35.98 & 33.04 & 22.35 & $\mathrm{~L}$ & 4.99 \\
\hline
\end{tabular}

'LUE, lysine utilization efficiency

${ }^{2} \mathrm{CV}(\%)$, coefficient of variation; *L, Linear effect; ${ }^{*} \mathrm{Q}$, quadratic effect $(p<0.05)$. The equations are shown in Table 10. 
Brasil RJM, Lima CAR, Machado NJB, Curvello FA, Quaresma DV, Vieites FM, Sousa FDR

\section{Digestible Lysine Requirements the Performance, Carcass Traits and Breast Meat Quality of Slow- Growing Broilers}

Table 5 - Carcass and parts yields and relative weights of edible offal and abdominal fat of slow-growing broilers slaughtered at 70 days of age in experiment 2.

\begin{tabular}{|c|c|c|c|c|c|c|c|}
\hline \multirow[b]{2}{*}{ Variables } & \multicolumn{5}{|c|}{ Digestible lysine (\%) } & \multirow[b]{2}{*}{ Regression* } & \multirow[b]{2}{*}{$\mathrm{CV}^{1}(\%)$} \\
\hline & 0.803 & 0.943 & 1.083 & 1.223 & 1.363 & & \\
\hline \multicolumn{8}{|l|}{ Yield (\%) } \\
\hline Carcass & 69.38 & 69.68 & 73.63 & 75.89 & 64.30 & Q & 2.91 \\
\hline Breast & 26.30 & 28.40 & 28.25 & 28.68 & 27.02 & $\mathrm{Q}$ & 6.32 \\
\hline Leg & 27.14 & 28.27 & 29.15 & 29.06 & 27.36 & Q & 8.85 \\
\hline Wing & 12.85 & 13.08 & 13.30 & 13.12 & 13.10 & Q & 5.11 \\
\hline Back & 25.79 & 32.48 & 26.72 & 25.62 & 28.99 & NS & 8.59 \\
\hline \multicolumn{8}{|c|}{ Relative weight (\%) } \\
\hline Heart & 0.37 & 0.37 & 0.36 & 0.35 & 0.38 & NS & 12.81 \\
\hline Liver & 1.50 & 1.35 & 1.38 & 1.37 & 1.40 & NS & 14.15 \\
\hline Gizzard & 1.84 & 1.71 & 1.76 & 1.77 & 1.65 & NS & 19.89 \\
\hline Abdominal fat & 1.64 & 1.49 & 1.26 & 1.33 & 1.78 & $\mathrm{Q}$ & 40.24 \\
\hline
\end{tabular}

${ }^{1} \mathrm{CV}$, Coefficient of variation;

*NS, Not significant; * $L$, Linear effect; ${ }^{*} Q$, quadratic effect $(p<0.05)$. The equations are shown in Table 10.

The highest carcass yield (74.24\%), breast yield (28.74\%), leg yield (29.15\%) and wing yield (13.21\%) were obtained at estimated digestible lysine values of $1.068,1.107,1.101$ and $1.142 \%$, respectively. The lowest relative weight of abdominal fat $(1.31 \%)$ was achieved at an estimated digestible lysine value of $1.075 \%$.

The lowest abdominal fat relative weight (1.31\%) was calculated at an estimated digestible lysine value of $1.075 \%$. The dietary excessive supply of amino acids can lead to imbalances, limiting lean tissue growth and increasing fat deposition. The supply of diets with protein in excess of the requirements or lowdigestibility proteins results in amino acid imbalance. Therefore, the excessive amino acids that are not utilized by the body need to be deaminated, resulting in carbohydrates that are used as energy source, increasing the potential for fat deposition (Lesson, 1995), which may explain the increase in abdominal fat in the broilers fed the diet containing the highest digestible lysine value (1.363\%).

\section{Breast meat quality}

The breast meat quality parameter results are shown in Table 6.

Breast meat moisture and crude protein contents linearly increased as dietary digestible lysine increased in $1.39 \%$ and $6.23 \%$, respectively. The linear response observed in breast meat moisture content may be partially explained by the increase in crude

Table 6 - Chemical and physical-chemical composition of the breast meat of slow-growing broilers slaughtered at 70 days of age in experiment 2 .

\begin{tabular}{|c|c|c|c|c|c|c|c|}
\hline \multirow[b]{2}{*}{ Variables } & \multicolumn{5}{|c|}{ Digestible lysine (\%) } & \multirow[b]{2}{*}{ Regression* } & \multirow[b]{2}{*}{$\mathrm{CV}^{7}(\%)$} \\
\hline & 0.803 & 0.943 & 1.083 & 1.223 & 1.363 & & \\
\hline \multicolumn{8}{|c|}{ Chemical composition (\%)** } \\
\hline Humidity & 73.07 & 73.00 & 73.21 & 73.89 & 74.10 & $\mathrm{~L}$ & 7.89 \\
\hline Crude protein & 22.13 & 22.71 & 22.97 & 23.38 & 23.60 & $\mathrm{~L}$ & 6.54 \\
\hline Ether extract & 1.43 & 1.34 & 1.42 & 1.09 & 0.85 & L & 7.00 \\
\hline Ash & 1.44 & 1.43 & 1.45 & 1.40 & 1.40 & NS & 5.43 \\
\hline \multicolumn{8}{|c|}{ Physical-chemical composition } \\
\hline $\mathrm{pH}$ & 6.21 & 5.89 & 6.03 & 6.13 & 5.97 & NS & 3.25 \\
\hline $\operatorname{TWL}^{1}(\%)$ & 4.92 & 5.02 & 5.56 & 7.65 & 6.54 & $\mathrm{~L}$ & 3.14 \\
\hline $\mathrm{CWL}^{2}(\%)$ & 18.63 & 18.98 & 19.21 & 19.14 & 19.91 & $L$ & 2.67 \\
\hline $\mathrm{SS}^{3}(\mathrm{kgf} / \mathrm{g})$ & 3.33 & 3.14 & 3.24 & 3.45 & 3.29 & NS & 18.21 \\
\hline$L^{* 4}$ & 46.98 & 47.32 & 46.34 & 46.12 & 47.24 & NS & 24.54 \\
\hline$a * 5$ & 5.70 & 5.88 & 6.01 & 5.90 & 6.10 & $\mathrm{~L}$ & 20.78 \\
\hline$b * 6$ & 9.75 & 9.78 & 10.23 & 9.89 & 10.06 & NS & 29.97 \\
\hline
\end{tabular}

'TWL, Thawing weight loss; ${ }^{2} \mathrm{CWL}$, Cooking weight loss; ${ }^{3} \mathrm{SS}=$ Shear Strength

${ }^{4}$ Lightness; ${ }^{5}$ Redness; ${ }^{6}$ Yellowness

${ }^{7} \mathrm{CV}$, Coefficient of variation; *NS, Not significant; * $\mathrm{L}$, Linear effect $(p<0.05)$

**Values determined in fresh meat. 
Brasil RJM, Lima CAR, Machado NJB, Curvello FA, Quaresma DV, Vieites FM, Sousa FDR

\section{Digestible Lysine Requirements the Performance, Carcass Traits and Breast Meat Quality of Slow- Growing Broilers}

Relative to breast meat color, meat redness linearly increased with increasing dietary digestiblelysine levels. This result may be due a significant increase in oxidative muscle fibers (red color) (Ono et al., 1993). In addition, the higher $b^{*}$ values (yellowness) in relation to $a^{*}$ values (redness) obtained in the present study are consistent with the report of Souza et al. (2004), who observed thatthe breast muscle of poultry tends to present higher yellowness (higher $b$ * values relative to $a^{*}$ values) compared with the meat of other animal species.

\section{Experiment 3 - Performance, carcass traits, and of breast meat quality results obtained in the finisher phase (70 to 84 days old)}

\section{Performance and carcass traits}

Dietary digestible lysine values influenced in a quadratic manner feed intake, weight gain and feed conversion ratio, and in a linear manner lysine intake and utilization efficiency (Table 7). The best weight gain $(1007 \mathrm{~g})$ and feed conversion ratio (2.87) results were obtained at estimated dietary digestible lysine levels of 1.162 and $1.126 \%$, respectively (Table 10 ). These results are consistent with those obtained by Nascimento et al. (2016), who evaluated the effects of increasing digestible lysine values on the performance of broilers of the slow-growing strain Embrapa 041 during the period of 35-84 days of age and estimated digestible lysine requirements of 1.196 and $1.078 \%$ for optimal weight gain and feed conversion ratio, respectively.

Table 7 - Feed intake, weight gain, feed conversion ratio and lysine intake and utilization efficiency of slow-growing broilers in experiment 3 (70 to 84 days old).

\begin{tabular}{|c|c|c|c|c|c|c|c|}
\hline \multirow[b]{2}{*}{ Variables } & \multicolumn{5}{|c|}{ Digestible lysine (\%) } & \multirow[b]{2}{*}{ Regression* } & \multirow[b]{2}{*}{$\mathrm{CV}^{2}(\%)$} \\
\hline & 0.766 & 0.906 & 1.046 & 1.186 & 1.326 & & \\
\hline Feed intake, $\mathrm{g}$ & 2941 & 2886 & 2826 & 2843 & 2853 & Q & 6.47 \\
\hline Weight gain, g & 928 & 949 & 990 & 1040 & 977 & Q & 5.91 \\
\hline Feed conversion ratio & 3.23 & 3.10 & 2.88 & 2.81 & 3.03 & Q & 7.66 \\
\hline Lysine intake, g & 23.92 & 26.03 & 27.80 & 32.84 & 38.79 & $\mathrm{~L}$ & 5.28 \\
\hline $\operatorname{LUE}^{1}(\%)$ & 36.22 & 31.71 & 36.83 & 26.63 & 21.41 & $L$ & 6.45 \\
\hline
\end{tabular}

'LUE, lysine utilization efficiency

${ }^{2} \mathrm{CV}(\%)$, coefficient of variation; ${ }^{*} L$, Linear effect; ${ }^{*} Q$, quadratic effect $(p<0.05)$. The equations are shown in Table 10.

The lowest feed intake (2832g) obtained in this phase was obtained at an estimated digestible lysine of $1.150 \%$. In all experiments, feed intake decreased to a minimum and then increased as a function of dietary digestible lysine levels, which may be due to an improvement in the ratio of lysine to the other amino acids present in the diet (Conhalato et al., 1999) and subsequent worsening of this relationship, when lysine was supplied in excess of the requirements.

Dietary digestible lysine values had a quadratic effect on carcass, breast and wing yields, and a linear effect on leg yield (Table 8). The best carcass yield (69.34\%), breast yield (26.96\%) and leg yield (31.95\%) results were obtained at estimated dietary digestible lysine of $1.065,1.195$ and $1.107 \%$, respectively. 


\section{Digestible Lysine Requirements the Performance, Carcass Traits and Breast Meat Quality of Slow- Growing Broilers}

Table 8 - Carcass and parts yields and relative weights of edible offal and abdominal fat of slow-growing broilers slaughtered at 85 days of age in experiment 3.

\begin{tabular}{|c|c|c|c|c|c|c|c|}
\hline \multirow[b]{2}{*}{ Variables } & \multicolumn{5}{|c|}{ Digestible lysine (\%) } & \multirow[b]{2}{*}{ Regression* } & \multirow[b]{2}{*}{$C V^{1}(\%)$} \\
\hline & 0.776 & 0.906 & 1.046 & 1.186 & 1.326 & & \\
\hline \multicolumn{8}{|l|}{ Yield (\%) } \\
\hline Carcass & 65.47 & 67.49 & 68.31 & 70.60 & 65.21 & Q & 4.51 \\
\hline Breast & 26.39 & 26.76 & 26.87 & 26.93 & 26.92 & Q & 5.90 \\
\hline Leg & 30.91 & 31.15 & 31.97 & 32.17 & 31.29 & Q & 10.67 \\
\hline Wing & 12.14 & 12.32 & 12.19 & 12.34 & 12.55 & NS & 8.56 \\
\hline Back & 24.60 & 25.38 & 25.31 & 25.77 & 24.15 & NS & 12.95 \\
\hline \multicolumn{8}{|c|}{ Relative weight (\%) } \\
\hline Heart & 0.40 & 0.39 & 0.41 & 0.41 & 0.40 & NS & 9.19 \\
\hline Liver & 1.59 & 1.62 & 1.63 & 1.66 & 1.71 & NS & 16.21 \\
\hline Gizzard & 2.06 & 2.00 & 2.00 & 2.02 & 2.06 & NS & 21.01 \\
\hline Abdominal fat & 2.45 & 3.15 & 2.97 & 3.68 & 4.05 & L & 51.42 \\
\hline
\end{tabular}

${ }^{1} \mathrm{CV}$, Coefficient of variation;

${ }^{*}$ NS, Not significant; *L, Linear effect; ${ }^{*} Q$, quadratic effect $(p<0.05)$. The equations are shown in Table 10.

These results are consistent with the findings of Rezaei et al. (2004), who described that dietary lysine levels may affect meat production, particularly breast meat yield, as this cut represents a large percentage of the carcass and contains significant amounts of lysine. According to Leclerca (1998), the breast muscle is the tissue that most profits from high dietary lysine values, as lysine is the main amino acid in breast muscle fibers. Breast development is directly related to body weight and muscle protein deposition and contributes to increase carcass weight, as reported by Trindade Neto et al. (2009) and Rosa et al. (2014), who observed that protein deposition in the breast muscle increased as a function of increasing dietary digestible lysine levels, resulting in higher breast yield, and consequently, higher carcass yield.

Giblet relative weights were not affected by the treatments $(p>0.05)$. On the other hand, abdominal fat relative weight linearly increased as a function of dietary digestible lysine values. This result may be partially explained by the fact that feeding amino acids in excess of the requirements may limit lean tissue growth and increased fat deposition, as discussed in experiment 2. This effect is undesirable for both production and economic reasons: in addition of reducing carcass yield and feed efficiency (Gaya \& Ferraz, 2006), chicken carcasses and cuts presenting excessive fat are rejected by the consumers (Meza et al., 2015).

\section{Breast meat quality}

No significant effects of dietary digestible lysine values on the chemical composition of breast meat were detected in broilers slaughtered at 84 days of age (Table 9). These results are in agreement with those of
Takeara et al. (2010) and Oliveira et al. (2013), who did not find any influence of dietary digestible lysine levels on the chemical composition of broiler carcasses.

The same effect of the dietary treatments on TWL of broilers slaughtered at 70 days of age (Experiment 2) was observed in Experiment 3. Although fresh meat moisture content was not different among treatments, significant TWL were observed, and the reasons for this result were previously discussed in experiment 2 .

Meat texture is directly related to the amount of intramuscular water content and meat water-holding capacity; therefore, the higher the water content in muscle, the greater the meat tenderness (Anadón, 2002). However, meat tenderness, as determined by shear strength, was not significantly affected. The linear increase in TWL and CWL observed as dietary digestible lysine levels increased did not contribute reduce shear strength. These effects did not negatively influence meat tenderness because the mean value obtained in the present study was $3.90 \mathrm{kgf} / \mathrm{g}$, and the reference value adopted by many authors for hardboiled breast meat is $7.5 \mathrm{kgf} / \mathrm{g}$, according to Lyon et al. (1985).

In general, the lysine requirements estimated in the present study are higher than those calculated in previous studies conducted with broilers of low genetic potential for growth (Nascimento et al., 2009; Oliveira et al., 2013; Rosa et al., 2014). Moreover, the obtained values are also higher than those used in reference tables, such as the Brazilian Tables for Poultry and Swine (Rostagno et al., 2011), or in manuals of genetic strains, such as the recommendations for Cobb broilers (Cobb-Vantress, 2013) and for Cobb Sasso 150 broilers (Cobb-Vantress, 2008). 
Brasil RJM, Lima CAR, Machado NJB, Curvello FA, Quaresma DV, Vieites FM, Sousa FDR

\section{Digestible Lysine Requirements the Performance, Carcass Traits and Breast Meat Quality of Slow- Growing Broilers}

Table 9 - Chemical and physical-chemical composition of the breast meat of slow-growing broilers slaughtered at 85 days of age in experiment 3.

\begin{tabular}{|c|c|c|c|c|c|c|c|}
\hline \multirow[b]{2}{*}{ Variables } & \multicolumn{5}{|c|}{ Digestible lysine (\%) } & \multirow[b]{2}{*}{ Regression* } & \multirow[b]{2}{*}{$\mathrm{CV}^{7}(\%)$} \\
\hline & 0.766 & 0.906 & 1.046 & 1.186 & 1.326 & & \\
\hline \multicolumn{8}{|c|}{ Chemical composition $(\%)^{\star *}$} \\
\hline Moisture & 73.12 & 72.96 & 73.09 & 73.22 & 72.89 & NS & 5.67 \\
\hline Crude protein & 23.39 & 23.42 & 23.34 & 23.38 & 23.31 & NS & 6.32 \\
\hline Ether extract & 1.54 & 1.49 & 1.51 & 1.50 & 1.45 & NS & 6.78 \\
\hline Ash & 1.49 & 1.55 & 1.49 & 1.53 & 1.48 & NS & 4.98 \\
\hline \multicolumn{8}{|c|}{ Physical-chemical composition } \\
\hline $\mathrm{pH}$ & 5.94 & 5.95 & 5.94 & 5.89 & 5.97 & NS & 2.98 \\
\hline $\operatorname{TWL}^{1}(\%)$ & 3.87 & 4.22 & 4.51 & 6.12 & 5.54 & L & 3.02 \\
\hline $\mathrm{CWL}^{2}(\%)$ & 15.39 & 15.76 & 16.68 & 16.43 & 17.12 & L & 3.45 \\
\hline $\mathrm{SS}^{3}(\mathrm{kgf} / \mathrm{g})$ & 3.78 & 3.98 & 3.87 & 3.93 & 3.92 & NS & 20.32 \\
\hline$L^{* 4}$ & 48.56 & 49.54 & 48.67 & 48.67 & 49.14 & NS & 23.83 \\
\hline$a^{* 5}$ & 6.73 & 6.69 & 6.71 & 6.74 & 6.69 & NS & 18.34 \\
\hline$b^{\star 6}$ & 8.16 & 8.45 & 9.65 & 8.43 & 9.23 & NS & 25.99 \\
\hline
\end{tabular}

${ }^{1} \mathrm{TWL}$, Thawing weight loss; ${ }^{2} \mathrm{CWL}$, Cooking weight loss; ${ }^{3} \mathrm{SS}=$ Shear Strength

${ }^{4}$ Lightness; ${ }^{5}$ Redness; ${ }^{6}$ Yellowness

${ }^{7} \mathrm{CV}$, Coefficient of variation; *NS, Not significant; ${ }^{*} L$, Linear effect $(p<0.05)$

**Values determined in fresh meat

The higher estimates calculated in the present study may partly be due to differences in the calculation of the amino acid requirements (percentage), as well as to genetic strain. According to Baker \& Han (1994), conventional broiler strains require almost the double amount of amino acids (milligrams) compared with slow-growing strains; however, this difference is offset

Table 10 - Summary of digestible lysine requirements of slow-growing broilers.

\begin{tabular}{|c|c|c|c|}
\hline \multicolumn{4}{|c|}{ Experiment 1 (29-49 days old) } \\
\hline Item & Estimated value (\%) & $R^{2}$ & Quadratic regression ${ }^{1}$ \\
\hline Feed intake, $\mathrm{g}$ & 1.298 & 0.93 & $\hat{Y}=1140.7 x^{2}-2962.3 x+4645.9$ \\
\hline Weight gain, $\mathrm{g}$ & 1.183 & 0.74 & $\hat{Y}=-2208.5 x 2+5223.9 x-1939.7$ \\
\hline Feed conversion ratio & 1.203 & 0.91 & $\hat{Y}=6.0496 \times 2-14.555 x+10.995$ \\
\hline Carcass yield (\%) & 1.162 & 0.87 & $\hat{Y}=-81.086 x 2+188.4 x-35.814$ \\
\hline Wing yield (\%) & 1.179 & 0.61 & $\hat{Y}=-5.9038 \times 2+13.548 x+5.6194$ \\
\hline \multicolumn{4}{|c|}{ Experiment 2 (50-69 days old) } \\
\hline Feed intake, $\mathrm{g}$ & 1.109 & 0.90 & $\hat{Y}=2809.8 x 2-6296.7 x+7019.4$ \\
\hline Weight gain, $g$ & 1.199 & 0.73 & $\hat{Y}=-579.45 \times 2+1390.1 x+73.683$ \\
\hline Feed conversion ratio & 1.162 & 0.87 & $\hat{Y}=3.7536 x 2-8.7233 x+8.2735$ \\
\hline Carcass yield (\%) & 1.068 & 0.60 & $\hat{Y}=-92,821 x 2+198,23 x-31.598$ \\
\hline Breast yield (\%) & 1.107 & 0.89 & $\hat{Y}=-25,292 \times 2+56,01 x-2.2733$ \\
\hline Leg yield $(\%)$ & 1.101 & 0.95 & $\hat{Y}=-24,162 \times 2+53,213 x-0.1475$ \\
\hline Wing yield (\%) & 1.142 & 0.85 & $\hat{Y}=-3,2799 x 2+7,936 x+8.4294$ \\
\hline Abdominal fat (\%) & 1.075 & 0.88 & $\hat{Y}=5.4665 x 2-12.498 x+8.429$ \\
\hline \multicolumn{4}{|c|}{ Experiment 3 (70-84 days old) } \\
\hline Feed intake, $\mathrm{g}$ & 1.150 & 0.95 & $\hat{Y}=754.37 x 2-1734.6 x+3829.2$ \\
\hline Weight gain, $g$ & 1.162 & 0.73 & $\hat{Y}=-579,45 \times 2+1347,2 x+224.32$ \\
\hline Feed conversion ratio & 1.126 & 0.87 & $\hat{Y}=3,0977 x 2-6,9732 x+6.7933$ \\
\hline Carcass yield (\%) & 1.065 & 0.68 & $\hat{Y}=-48,652 x 2+103,63 x+14.158$ \\
\hline Breast yield (\%) & 1.195 & 0.98 & $\hat{Y}=-2,9519 \times 2+7,0539 x+22.741$ \\
\hline Leg yield $(\%)$ & 1.107 & 0.76 & $\hat{Y}=-10,423 \times 2+23,076 x+19 \cdot 173$ \\
\hline
\end{tabular}

${ }^{1}$ Regression was significant $(p<0.05)$. by the daily feed intake of chickens of conventional lines. This result suggests that, as a percentage, the requirements of broiler with lower growth genetic potential may be higher due to their lower daily feed intake compared with conventional broiler strains.

The summary of the digestible lysine requirements estimates according to rearing phase, as determined by quadratic regression, with their respective equations and coefficients of determination are described in Table 10.

\section{CONCLUSIONS}

Digestible lysine levels of 1.203, 1.162 and $1.126 \%$ are recommended in the diets of Redbro Plume broilers during the phases 29-49, 50-69 and 70-84 days of age, respectively, to optimize feed conversion ratio.

Increasing dietary digestible lysine values affect the chemical composition (moisture, protein and ether extract contents) of the breast meat of broilers slaughtered at 70 days of age and thawing and cooking weight loss of the breast meat of broilers slaughtered at 70 and 85 days of age.

\section{REFERENCES}

Alam MR, Yoshizawa F, Sughara K. Oral administration of lysine restores food intake and ventromedial hypothalamic dopamine in chicken on alysine-free diet. British Poultry Science 2012;53(5):651-657. 
Brasil RJM, Lima CAR, Machado NJB, Curvello FA, Quaresma DV, Vieites FM, Sousa FDR

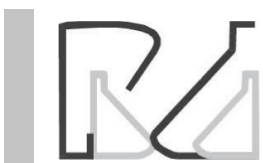

Almeida EU. Nutrição para frangos de corte machos de 1 a 42 dias de idade [dissertation]. Vila Velha (ES): Centro Universitário Vila Velha; 2010.

Anadón HLS. Biological, nutritional and processing factors affecting breast meat quality of broilers [thesis]. Blacksburg (VA): Faculty of Virginia Polytechnic Institute and State University; 2002.

Baker DH, Han Y. Ideal amino acid profile for chicks during the first three weeks posthatching. Poultry Science 1994;73:1441-1447.

Brasil. Ministério da Agricultura, Pecuária e Abastecimento. Instrução normativa $n^{\circ} 46$, de 6 de outubro de 2011. Dispõe sobre regulamento técnico para os sistemas orgânicos de produção, bem como as listas de substâncias e práticas permitidas para uso nos sistemas orgânicos de produção. Brasília, DF; 2014 [cited 2016 Mar 10]. Available from: http:// www.agricultura.gov.br/arq_editor/file/Desenvolvimento_Sustentavel/ Organicos/Legislacao/Nacional/Instrucao_Normativa_n_0_046_de_0610-2011_regulada_pela_IN_17.pdf.

Champe PC, Harvey RA, Ferrier DR. Bioquímica ilustrada. Porto Alegre (RS): Editora Artmed;2009. p. 528.

Cobb-Vantress. Cobb Sasso150: broiler performance \& nutrition supplement. Arkansas: A.R Performance targets and recommendations on nutritional specifications; 2008

Cobb-Vantress. Suplemento: desempenho e nutrição para frangos de corte Cobb 500. Arkansas : A.R Performance targets and recommendations on nutritional specifications; 2013.

Conhalato GS, Donzele JL, Albino LFT, Oliveira RFM, Fontes DO. Níveis de lisina digestível para frangos de corte machos na fase de 22 a 42 dias de idade. Revista Brasileira de Zootecnia 1999;28(1):98-104

Costa FGP, Rostagno HS, Albino LFT, Gomes PC, Toledo RS. Níveis dietéticos de lisina para frangos de corte de 1 a 21 e 22 a 40 dias de idade. Revista Brasileira de Zootecnia 2001;30(5):1490-1497.

Dabés AC. Propriedades da carne fresca. Revista Nacional da Carne 2001;25:32-40.

Ferreira DF. Sisvar: a computer statistical analysis system. Ciência e Agrotecnologia 2011;35(6):1039-1042.

Gaya LG, Ferraz JBS. Aspectos genético-quantitativos da qualidade da carne em frangos. Ciência Rural 2006;36(1):349-356.

Gonzales E. Ingestão de alimentos: mecanismos regulatórios. In: Macari M, Furlan RL, Gonzales E, editors. Fisiologia aviária aplicada a frangos de corte. Jaboticabal: FUNEP; 2002. p.187-199.

Lana SRV, Oliveira RFM, Donzele JL, Gomes PC, Vaz RGMV, Resende WO. Níveis de lisina digestível em rações para frangos de corte de 22 a 42 dias de idade, mantidos em ambiente de termoneutralidade. Revista Brasileira de Zootecnia 2005;34(5):1624-1632.

Leclercq B. Specific effects of lysine on broiler production: comparison with threonine and valine. Poultry Science 1998;77:118-123

Leeson, S. Nutrição e qualidade da carcaça de frangos de corte. Anais da Conferência Apinco de Ciências e Tecnologia Avícolas;1995; Curitiba, Paraná. Brasil. p.118-123.

Lyon CF, Hamm DE, Thomson JE. pH and tenderness of broiler breast meat deboned various times after chilling. Poultry Science 1985;64:307-310.

Meza SKL, Nunes RVN, Tsutsumi CY, Vieites FM, Scherer C, Henz JR, et al. Níveis de energia metabolizável e lisina digestível sobre a composição e rendimento de carcaça de frangos de corte. Semina: Ciências Agrárias 2015;36(2):1079-1090.

Miranda RL, Silva FOC, Lima JCS, Castro JR, Quirino RC, Severino RS, Drummond SS. Origem e distribuição da artéria celíaca em aves (Gallusgallus) de corte da linhagem Red Bro Plumé. Bioscience Journal 2005;21(3):77-83.

Nascimento DCN, Sakomura NK, Siqueira JC, Dourado LRB, Fernandes JBK, Malheiros EB. Exigências de lisina digestível para aves de corte da

\section{Digestible Lysine Requirements the Performance, Carcass Traits and Breast Meat Quality of Slow- Growing Broilers}

linhagem Isa Label criadas em semiconfinamento. Arquivos Brasileiros de Medicina Veterinária e Zootecnia 2009;61(5):1128-1138.

Nascimento ES, Lima CAR, Brasil RJM, Machado NJB, Sousa FDR, Corrêa GSS. Digestible lysine for broiler chickens with lower genetic potential grown on free-range system. Ciência e Agrotecnologia 2016;40(4):454463.

Oliveira HG, Carrijo AS, Kiefer C, Garcia ERM, Oliveira JA, Silva JB, et al. Lisina digestível em dietas de baixa proteína para frangos de corte tipo caipira de um aos 28 dias. Arquivos Brasileiros de MedicinaVeterinária e Zootecnia 2013;65(2):497-504.

Ono $\mathrm{Y}$, Iwamoto $\mathrm{H}$, Takahara $\mathrm{H}$. The relationship between muscle growth and the growth of different fiber types in the chicken. Poultry Science $1993 ; 72: 548-576$

Pedroso AC, Franco SG, Flemming JS, Borges SA, Sillus PP. Performace and carcass yield of broiler fed with diferente digestible amino acid profiles recommended by nutrients requeriments tables. Revista Brasileira de Ciência Avícola 2003;5(1):29-35.

Pinheiro SRF, Sakomura NK, Nascimento DCN, Dourado LRB, Fernandes JBK, Thomaz MC. Níveis nutricionais de fósforo disponível para aves de corte Isa Label criadas em semiconfinamento. Revista Brasileira de Zootecnia 2011a;40(2):361-369.

Pinheiro SRF, Sakomura NK, Siqueira JC, Marcato SM, Dourado LRB, Fernandes JBK, et al. Níveis nutricionais de cálcio para aves de corte Isa Label criadas sob semiconfinamento. Arquivos Brasileiros de Medicina Veterinária e Zootecnia 2011b;63(1):231-238.

Rezaei M, Moghaddam HN, Reza JP, Kermanshahi H. The effects of dietary protein and lysine levels on broiler performance, carcass characteristics and N excretion. Poultry Science 2004;3:148-152.

Rosa EPM, Kiefer C, Souza KMR, Silva JB, Ozelame AM, Gomes ENO, et al. Níveis de lisina digestível para frangos de corte tipo caipira de 28 a 56 dias de idade. Revista Brasileira de Saúde e Produção Animal 2014;15(4):872-880.

Rostagno HS, Albino LFT, Donzele JL, Gomes PC, Oliveira RF, Lopes DC, et al. Tabelas brasileiras para aves e suínos: composição de alimentos e exigências nutricionais. $3^{\text {rd }} \mathrm{ed}$. Viçosa (MG): Universidade Federal de Viçosa; 2011. 252p.

Sandel LJ, Daniel JC. Effects of ascorbic acid on collagen mRNA levels in short-term chondrocyte cultures. Connective Tissue Research 1988:17(1):11-22

Silva DJ, Queiroz AC. Análise de alimentos: métodos químicos e biológicos. Viçosa (MG): Editora UFV; 2006. p.235

Sklan D, Noy Y. Catabolism and deposition of amino acids in growing chicks: effect of dietary suplly. Poultry Science 2004;83:952-961.

Souza XR, Bressan MC, Pérez JRO, Faria PB, Vieira JO, Kabeya DM. Efeitos do grupo genético, sexo e peso ao abate sobre as propriedades físicoquímicas da carne de cordeiros em crescimento. Ciência e Tecnologia de Alimentos 2004;24(4):543-549.

Takeara P, Toledo AL, Gandra ERS, Albuquerque R, Trindade Neto MA Lisina digestível para frangos de corte machos entre 12 e 22 dias de idade. Arquivos Brasileiros de Medicina Veterinária e Zootecnia 2010;62(6):1455-1461.

Trindade Neto MA, Takeara P, Toledo AL, Kobashigawa E, Albuquerque $R$, Araújo LF. Níveis de lisina digestível para frangos de corte machos no período de 37 a 49 dias de idade. Revista Brasileira de Zootecnia 2009;38(3):508-514.

Trindade Neto MA, Toledo AL, Takeara P, Kobashigawa E, Donato DCZ, Albuquerque R. Dietary levels of lysine for male broilers from 23 to 36 days of age: performance and body composition. Revista Brasileira de Zootecnia 2011;40(3):609-615. 